
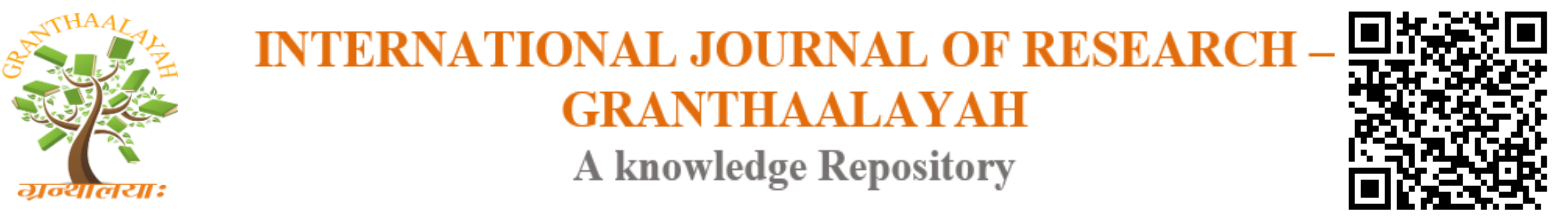

Science

\title{
RED BLOOD CELL MORPHOLOGY: STILL AN IMPORTANT TOOL FOR ANEMIA TYPING
}

\author{
Dr. Ekta Patidar *1
}

${ }^{* 1}$ Consultant Pathologist, Sampurna Sodani Diagnostic Clinic, Indore, Madhya Pradesh, India

\begin{abstract}
Anemia is a common entity which every clinician and pathologist faces very frequently. Proper clinical history, physical examination and laboratory investigations are essential for diagnostic interpretation of anemia. Peripheral blood examination is a basic screening haematological tool used for its evaluation.
\end{abstract}

Keywords: Red Blood Cell Morphology, Anemia, Peripheral Blood Examination.

Cite This Article: Dr. Ekta Patidar. (2018). "RED BLOOD CELL MORPHOLOGY: STILL AN IMPORTANT TOOL FOR ANEMIA TYPING." International Journal of Research - Granthaalayah, 6(3), 298-301. https://doi.org/10.29121/granthaalayah.v6.i3.2018.1530.

\section{Introduction}

Anemia is defined as decrease in the concentration of circulating haemoglobin or reduced oxygen carrying capacity of blood below the level that is expected for healthy persons of same age and sex in the given environment. It can affect all age groups but is predominantly seen in females. A battery of tests are available to diagnose and classify it but peripheral blood smear still remains a cheap and primary tool for anemia typing. Peripheral blood smear is made with a drop of blood, slide is stained and then examined under the microscope. ${ }^{(1)}$

A careful and thorough examination via light microscopy on a well made, well stained peripheral smear can provide important information about red blood cell morphology. ${ }^{(2)}$

\section{RBC Morphology}

On microscopy, a normal red cell is compared to the size of the nucleus of a small lymphocyte. The RBC has a diameter of 7-8 micron diameter on an average with central area diameter of about 2-3 micron.

Five important features which are to be studied for RBC morphology are shape, size, colour, inclusions and arrangement. 
Abnormal shape will indicate poikilocyte. Abnormal size denotes anisocytosis. Aberration from normal colour signifies hyper/hypo chromasia of the RBCs. Inclusions include Howell- jolly body, malaria parasite and nucleated RBCs. Phenomenon like Rouleaux formation and agglutination are abnormal arrangements of RBCs and need to be differentiated.

\subsection{Microscopic Picture for Microcytic Anemia}

RBC having diameter less than 7 micron in diameter and MCV of less than $80 \mathrm{fl}$ is an microcyte. $\mathrm{RBC}$ having central area of pallor more than 3 micron in diameter is hypochromic. Possible causes of microcytic hypochromic RBC are Iron deficiency anemia, Thalassemia, anemia of chronic disease, Sideroblastic anemia and lead poisoning.

The microscopic picture in Anemia of Chronic Disease is of unremarkable RBCs, while iron deficiency anemia gives a picture of anisocytosis, anisochromia and elliptocytosis. On the other hand thalassemia trait shows target cells and coarse basophilic stippling. ${ }^{(3)}$ Coarse basophilic stippling is also a feature of lead poisoning.

\subsection{Microscopic Picture for Macrocytic Anemia}

Macrocytes are cell that are approximately 9 micron or larger in diameter having MCV of greater than $100 \mathrm{fl}$. Causes of macrocytic anemia are megaloblastic anemia and non- megaloblastic anemia. Megaloblastic anemia is characterized by oval macrocytes (macroovalocytes) that may be 9 micron or more in diameter and lack central pallor. ${ }^{(4)}$ Megaloblastic anemia will have oval macrocytes, hyper segmented neutrophils and MCV greater than $120 \mathrm{fl}$. Megaloblastic anemia is seen in B12 and folate deficiency. The most common cause of non megaloblastic macrocytosis is accelerated erythropoiesis which results from condition such as acute blood loss or alcoholism. Macrocytes are also seen in hypothyroidism, Myelodysplastic Syndrome, liver disease, post splenectomy, neonates and pregnant women. Oval macrocytes are seen in Megaloblastic anemia compared to round macrocytes in non megaloblastic anemia.

\subsection{Microscopic Picture for Haemolytic Anemia}

Haemolytic anemia should be considered when there is a rapid fall in haemoglobin concentration, reticulocytosis, and/or abnormally shaped RBCs (especially spherocytes or fragmented RBCs) on the peripheral smear. ${ }^{(5)}$ Hemolytic anaemia occurs due to shortened survival of circulating red blood cells (RBCs).Red blood cell morphology which suggests haemolysis includes: -

Fragmented RBC indicates the presence of hemolytic anaemia of microangiopathic type.

Narrow and elongated red blood cells with one or both ends pointed are seen in sickle cell disease.

Bite cells are RBCs with bitten out margins which are seen in G6PD deficiency and unstable hemoglobin disease. Further assessment may be done by tests such as Heinz body test, G-6-PD level, and studies of red blood cell metabolism. ${ }^{(6)}$ 
Blister cells are irregularly contracted cells in which haemoglobin is condensed at one side of the cell. They are characteristic of glucose-6-phosphate dehydrogenase (G- 6-PD) deficiency and other conditions which cause oxidative stress on the RBC. ${ }^{(7)}$

An acanthocyte (spur cell) is defined as a cell of normal or slightly reduced size, which has 3 to 12 spicules of different lengths distributed along the periphery of the cell membrane. Acanthocytes are seen in cases of pyruvate kinase deficiency. Although they are also seen in conditions like congenital abetalipoproteinemia ${ }^{(8)}$, alcohol intoxication, liver diseases, vitamin $\mathrm{E}$ deficiency and post splenectomy patients.

Elliptocytes are characteristic of hereditary elliptocytosis. It can also be seen in thalassemia, sickle cell trait, and $\mathrm{Hb} \mathrm{C}$ trait. Rarely elliptocytes can occur in normal blood smears.

Nucleated red blood cells are immature red blood cells. It is seen due to accelerated erythropoiesis or severe bone marrow stress. Clinical conditions where NRBCs are seen are acute bleeding, severe hemolysis, myelofibrosis, leukemia, myelophthisis ${ }^{(9)}$

RBCs with inclusions are seen in Malaria, Babesiosis, and Bartonella infections.

\section{Conclusion}

History, physical examination and laboratory testing all are useful in evaluating an anemia patient. Red cell morphology elaborates about the type of anemia. Anemia is a clinical finding which needs evaluation and treatment as per the type accordingly. Careful examination of the peripheral smear helps to diagnose the type of anemia. Investigations like serum iron, serum ferritin, reticulocyte count serum bilirubin, lactate dehydrogenase, serum B12 and folate, hemoglobin electrophoresis, bone marrow examination etc are also useful in investigating the type of anemia but precise study of red cell morphology remains the basic investigation, importance of which cannot be overlooked.

\section{References}

[1] Ree GH, Sargeaunt PG. Letter: Laboratory diagnosis of malaria. Br Med J. 1976 Jan 17; 1(6002):152- 152.

[2] Munster M (2013). The role of the peripheral blood smear in the modern haematology laboratory. SEED haematology. Sysmex.

[3] Steine-Martin,E, et al: Clinical Haematology Principles,Procedures, Correlation. ed.2. LippincottRaven, Philadelphia,1998.

[4] Ford J. Red blood cell morphology. International Journal of laboratory Haematology. 2013.35, 351-357.

[5] Vikrant Kale and Abdur Rahmaan Aftab (2012). Diagnostic Evaluation of Anaemia, Anemia, Dr. Donald Silverberg (Ed.), ISBN: 978-953-51-0138-3, InTech.

[6] Yoo, D. and Lessin, L.S.. Drug-associated "bite cell" hemolytic anemia. Am. J. Med. 92(3): 243248, 1992.

[7] Abramson N. Inside blood: a picture (in the microscope) is worth a thousand words. Blood 2004; 103:367-368 CrossRef | Web of Science.

[8] Schmitz LL, McClure JS, Litz LE, et al. Morphologic and quantitative changes in blood and marrow cells following growth factor therapy. Am J Clin Pathol. 1994; 101:67-75. 
[9] Medical News: Nucleated RBCs in blood of adults should be cause for concern. JAMA. 1978; 239:91.

*Corresponding author.

E-mail address: dr.ektapatidar@gmail.com 